\title{
Mapping and Epidemiological analysis of types of Congenital Malformations in a Teaching Hospital
}

Cobo Daniel L ${ }^{1 *}$, Sciarra, Adília M.P², Batigália Fernando ${ }^{3}$, Monteiro, Vinicius H.F ${ }^{4}$, Neves Ricardo A. ${ }^{5}$, De Paula, Jaynne $\mathbf{L}^{5}$

${ }^{1}$ Master of Science in Health (Ms). Physiotherapist in Hospital of Base of São José do Rio Preto - SP.

Av. Brigadeiro Faria Lima, 5416, Vila São Pedro, CEP: 15.090-000, São José do Rio Preto, SP, Brasil.

${ }^{2}$ Doctor of Health Sciences (Dr). Postgraduate Education, Health Sciences, Faculty of Medicine of São José do Rio Preto - FAMERP.

${ }^{3}$ Doctor of Health Sciences (Dr). Department of Anatomy, Faculty of Medicine of São José do Rio Preto - FAMERP.

${ }^{4}$ Physiotherapist. Hospital of Base of São José do Rio Preto - SP.

${ }^{5}$ Physiotherapist.

*Corresponding Author: Cobo Daniel L, Av. Brigadeiro Faria Lima, 5416, Vila São Pedro, CEP: 15.090-000, São José do Rio Preto, SP, Brasil. Received Date: August 16, 2021; Accepted Date: September 13, 2021; Published Date: September 17,2021

Citation: Cobo Daniel L., Sciarra Adília M.P., Batigália Fernando., Monteiro Vinicius H.F., Neves Ricardo A., De Paula, Jaynne L.. (2021) Mapping and Epidemiological analysis of types of Congenital Malformations in a Teaching Hospital. J. Clinical Cardiology and Cardiovascular Interventions, 4(15); Doi:10.31579/2641-0419/214

Copyright: (C) 2021 Cobo Daniel L, This is an open-access article distributed under the terms of the Creative Commons Attribution License, which permits unrestricted use, distribution, and reproduction in any medium, provided the original author and source are credited.

Abstract
Introduction: The World Health Organization (WHO) defines as congenital malformation, all anomalies
triggered by the alteration of normal development resulting in a deficient formation from the initial stage of the
fetus still in intrauterine, whose origin occurs before birth, having causes genetic, environmental or unknown,
whether structural or functional, these disorders can be seen in prenatal care, childbirth, or even manifested in
childhood.
Background: To map and analyze epidemiological data on congenital malformations in children at a Teaching
Hospital in the interior of the State of São Paulo.
Materials and Methods: Data were collected from children with congenital malformations between the years
2010 and 2017 , searched through the International Disease Code (ICD 10 ) with codes from Q00 to Q89. During
the analysis of the medical records, 30,309 male and female children with congenital malformations were
identified, aged between 1 day and 12 years.
Results: 30,309 male and female children with congenital malformations were identified (16,956 male or
$54.75 \%$ and 13,713 female or $45.25 \%$ ) aged between 1 day and 12 years (19,587 from 0 to 4 years or $64.63 \%$;
5,780 from 5 to 8 years or $19.07 \%$ and 4,942 from 9 to 12 years or $16.30 \%$ ). The main types of congenital
malformations were found: cardiac and circulatory or $42.32 \%$; spinal cord or $12.34 \%$; congenital clubfoot or
$11.07 \%$; male and female genitals and urinary tracts or $8.97 \%$ which add up to $74.70 \%$.
Conclusion: Congenital malformations are rare anomalies and this study concluded that they are mostly
associated with male gender, early age and with a predominance of cardiac and circulatory alterations.
Key words: congenital malformations; anatomical variations and congenital abnormalities

\section{Introduction}

The World Health Organization (WHO) defines as congenital malformation, all anomalies triggered by the alteration of normal development resulting in a deficient formation from the initial stage of the fetus still in intrauterine, whose origin occurs before birth, having genetic causes, environmental or unknown, whether structural or functional, these disorders can be seen in prenatal care, childbirth, or even manifested in childhood. We have as congenital malformations those of the nervous system, musculoskeletal, digestive, chromosomal or genetic abnormalities, cleft lip and palate, circulatory, respiratory, urinary and genitourinary, hemangiomas and lymphangiomas. [1]
Congenital malformations can be classified as major, which would be severe anatomical, aesthetic and functional changes that can lead to death, or minor, which are mild mutations. About $5 \%$ of live births (LB) have some developmental anomaly, determined, in whole or in part, by genetic factors, and may last into adulthood, difficultly influencing the lives of individuals, families, health systems and society, requiring surgical procedures of an aesthetic or functional nature. [2,3]

Congenital anomalies accounted for 510,400 deaths worldwide in 2010 . In Brazil, in 2008, they corresponded to approximately $19 \%$ of mortality in children under one year of age, being responsible for the second leading cause of death in this age group. In the city of São Paulo from 2007 to 2011 , the prevalence of congenital anomalies was $1.2 \%$ of live births. In South America, Gil et al. assessed the prevalence rate of births with 
J Clinical Cardiology and Cardiovascular Interventions

congenital anomalies, and found that indicators of low socioeconomic conditions, such as low maternal education, age, infectious diseases and use of medications during pregnancy were detected as risk factors within these regions. Among the cleft lip anomalies with or without cleft palate, the ventricular septal defect presented a significantly higher risk in the lowest socioeconomic level. $[5,6,7,8]$

In many cases, congenital malformations are not fully attributed to a specific factor, but we can mention some factors that may be linked and justify certain malformations such as genetic factors through genes inherited from the sex chromosome or normal XY chromosome, triggering some type of morphological change, parental homogeneous blood type, environmental factors, socio-demographic factors (attributed by the possible lack of access to healthy foods), low health acuity such as prenatal care and limitations to information, infectious factors, low maternal weight and prematurity. The cardiovascular system is the most affected by congenital malformations, associated or not with other malformations. Congenital heart diseases account for $40 \%$ of all congenital defects, consisting of a structural change in the heart affecting the chambers, septa and/or large intrathoracic vessels, with important functional repercussions, requiring palliative or corrective surgical procedures. $[9,10]$

The study aims to map and analyze epidemiological data on congenital malformations in children at a Teaching Hospital in the interior of the State of São Paulo.

\section{MATERIALS AND METHODS}

Data collection was performed randomly in the computerized system regarding the care of children with congenital malformations at an outpatient or hospital level between 2010 and 2017, searched through the International Disease Code (ICD 10) with codes from Q00 to Q89
Copy rights@ Cobo Daniel L.et al

referring to the types of congenital malformations. During the analysis of the medical records, 30,309 male and female children with congenital malformations attended to in consultation or hospitalization, aged between 1 day and 12 years, were identified. All medical records of children who underwent evaluations, consultations, admissions and procedures at the Children and Maternity Hospital of São José do Rio Preto were included in the study, and the records that were repeated during the analysis and research were excluded.

Descriptive analyzes of each single variable were obtained using the Excel software and tool (version 2016). ${ }^{11}$ The variables considered in the study are categorical and include: types of malformations, age, sex. In the databases, the following descriptors were used: congenital malformations, anatomical variations and congenital anomalies, which were addressed together in the research. From the analysis of the references, only publications relevant to the present study were selected and, after consulting the databases, the articles were cataloged and analyzed, taking into account the data collected at the Children's and Maternity Hospital.

\section{RESULTS}

A total of 30,309 male and female children with Congenital Malformations attended to consultations or hospitalizations were identified (16,956 male or $54.75 \%$ and 13,713 female or $45.25 \%)$ aged between 1 day and 12 years $(19,587$ from 0 to 4 years or $64.63 \% ; 5,780$ from 5 to 8 years or $19.07 \%$ and 4,942 from 9 to 12 years or $16.30 \%$ ). The main types of congenital malformations were found: cardiac and circulatory or $42.32 \%$; spinal cord or $12.34 \%$; congenital clubfoot or $11.07 \%$; male and female genitals and urinary tracts or $8.97 \%$ which add up to $74.70 \%$ and the other congenital malformations $25.30 \%$.

\begin{tabular}{|c|c|c|}
\hline Sex & $\boldsymbol{N}$ & $\boldsymbol{\%}$ \\
\hline Male & 16956 & 54.75 \\
\hline Female & 13713 & 45.25 \\
\hline TOTAL & 30309 & 100.00 \\
\hline Average & & 50.00 \\
\hline
\end{tabular}

Table 1: Through descriptive analysis the table shows the percentage between male and female.

\begin{tabular}{|c|c|c|}
\hline Age Group & $\boldsymbol{N}$ & $\boldsymbol{\%}$ \\
\hline 0 a 4 years & 19587 & 64.63 \\
\hline 5 a 8 years & 5780 & 19.07 \\
\hline 9 a 12 years & 4942 & 16.3 \\
\hline TOTAL & 30309 & 10000 \\
\hline Average & & 33,33 \\
\hline
\end{tabular}

Table 2: Through descriptive analysis the table shows the percentage of ages by groups.

\begin{tabular}{|l|c|c|}
\hline \multicolumn{1}{|c|}{ Types of Malformations } & N & \% \\
\hline Cardiac and Circulatory & 12828 & 42.32 \\
\hline Spinal Cord & 3741 & 12.34 \\
\hline Congenital Clubfoot & 3356 & 11.07 \\
\hline Male and Female Urinary Tract and Genitals & 2721 & 8.97 \\
\hline Upper ande Lower Limb & 1448 & 4.77 \\
\hline Not Specified & 945 & 3.11 \\
\hline Ear & 882 & 2.91 \\
\hline Other Congenital malformations & 837 & 2.76 \\
\hline
\end{tabular}




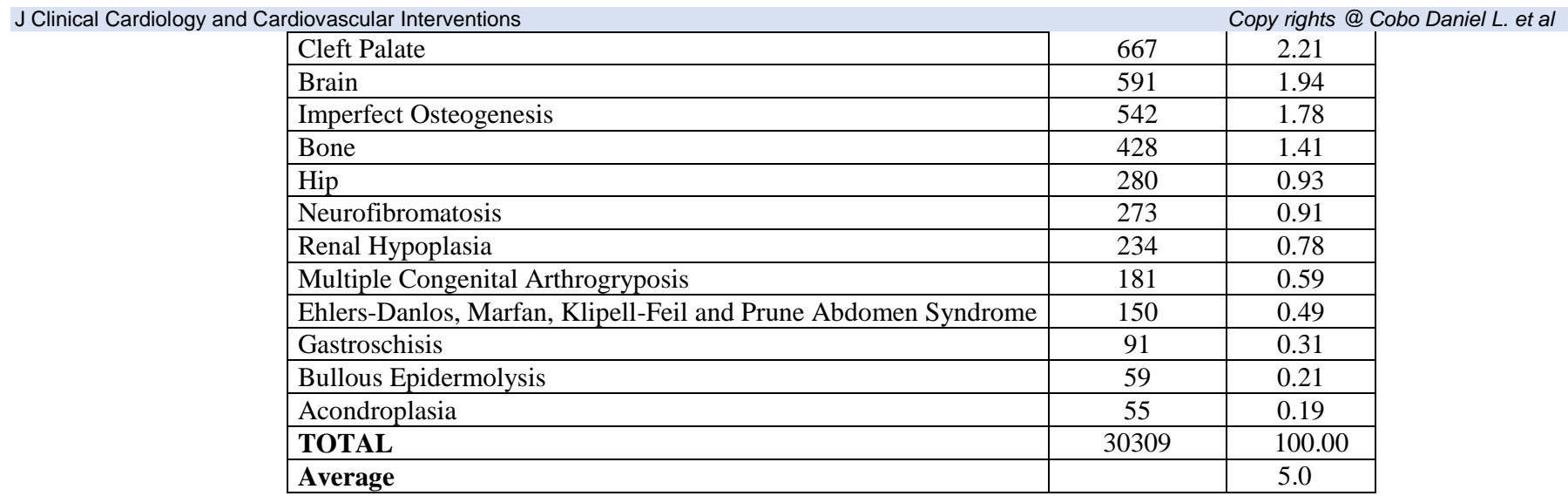

Table 3: Through descriptive analysis the table shows the types of congenital malformations.

\section{DISCUSSION}

Congenital malformations are rare anomalies, mostly associated with male gender, early age and with a predominance of cardiac and circulatory alterations.

Mendes et al, described that a study identified $1.2 \%$ of live births in the city of São Paulo with congenital malformations, with males having the highest incidence (50.9\%) Thus, Catarino et al, identified 1,086,139 live births with congenital malformations; among these, $345(4.3 \%)$ had congenital heart disease, representing a frequency of 3.18/10 thousand live births, $42.3 \%$ were girls, $56.4 \%$ boys and $1.3 \%$ had an unknown record regarding to sex. The most common malformations were: $3.2 \%$ unspecified polydactyly, $2.9 \%$ Down syndrome, $2.8 \%$ interatrial communication, $2.7 \%$ supernumerary finger(s) and $2.4 \%$ nonmalformation specified of the heart. [5,12]

Cosme et al, reported 14,657 congenital anomalies of 819,018 live births, the most frequent malformations of the osteoarticular system, mainly polydactyly and foot deformities, followed by malformations of the cardiovascular system and of the head and neck, are associated with greater findings in osteoarticular malformations for easier identification at the time of birth. However, Hurtado et al in their study in Risaralda Colombia, heart disease ranked first, followed by lip and palate, abdominal wall defects, skeletal dysplasia, hydrocephalus, polydactyl syndrome and Down syndrome. [7,13]

Murray et al report that oral clefts are craniofacial anomalies that require rehabilitation ranging from surgical intervention to nutritional, dental, speech therapy, medical and psychological guidance. Its occurrence is approximately 1 in 700 newborns worldwide, and it may vary according to geographic area and socioeconomic status. Most cleft lip and palate are the result of multiple factors, genetic and non-genetic, each causing a minor developmental disturbance.[14]

Congenital brain malformations affect about $1.94 \%$. According to Alberto et al, the brain is part of the central nervous system, contained in the skull cavity, and encompassing the brain, cerebellum, pons and medulla. Due to the complexity of its embryological development, its abnormal development in humans is not uncommon. Malformations of the nervous system, the driving force and coordinator of all vital manifestations, namely, the intellectual, the sensitive and the vegetative, were countless diseases. [15]

Horovitz et al, describe osteogenesis imperfecta (OI) as a rare disease, which affects $1.8 \%$ of cases, is characterized by bone fragility, recurrent fractures with secondary deformities, early deafness, bluish sclera and dentinogenesis imperfecta. Rodovalho et al, report that bone fragility and deformities, associated with recurrent fractures and short stature are characteristics of OI. These outcomes are attributed to mutations in genes responsible for the synthesis of type 1 collagen, being the central point of its pathophysiological mechanism. [16,17]
Picado-Vaquero et al report that hip instabilities have a prevalence of $1 \%$ to $1.5 \%$ in newborns, with females having the highest incidence of 13:1000 live births. These congenital hip changes encompass a wide spectrum of manifestations, such as acetabular dysplasia, hip subluxation and dislocation. According to Babock et al, clinical examination and imaging resources, such as radiography or ultrasound, contribute to the differential diagnosis of Developmental Hip Dysplasia (DHD). The Ortolani and Barlow tests, as well as the analysis of the size of the segments of the lower limbs, skinfold heights and family history, in addition to the type of delivery, are part of the clinical examination, guided by the pediatric orthopedist. [18,19]

Neurofibromatosis affects $0.91 \%$ of cases, it is an autosomal dominant disease. Lucchese et al report that it is a multisystemic affection with the possibility of ophthalmological, musculoskeletal, cardiovascular, endocrine, central and peripheral nervous system involvement. According to Friedman et al, neurofibromatosis is inherited from one of the parents in about $50 \%$ of cases. [20,21]

Maranhão et al state that congenital anomalies of the upper urinary tract, including milder forms, are not rare. In $0.98 \%$ newborns, there is some abnormality of the kidneys and ureters, with abnormalities in the shape and position of the kidneys being the most common. Congenital anomalies of the upper urinary tract imply morphofunctional changes with a variable clinical spectrum, from asymptomatic manifestations to renal failure and incompatibility with life. [22]

Congenital multiple arthrogryposis, $0.59 \%$ are part of the cases. Saccani et al, report that it was first described by Otto, in 1841 and believed that the pathological process was due to a congenital myodystrophy, however Stern, in 1923, called it "congenital multiple arthrogryposis". It is a rare syndrome that constitutes a heterogeneous group of congenital malformations of unknown etiology, multifactorial, characterized mainly by severe joint contractures and may be part of a complex of multisystemic congenital anomalies, such as musculoskeletal, genitourinary, cardiovascular, gastrointestinal, otorhinolaryngological and ophthalmological have been associated with congenital multiple arthrogryposis. [23]

Ehlers-Danlos Syndrome, Marfan, Klipell-Feil and Abdomen in Prune account for $0.49 \%$ of the cases. Espósito et al refer to Ehlers-Danlos as a term used for a group of relatively rare connective tissue pathologies. It is based on hereditary alterations in genes that affect the synthesis of different forms of collagen, without a predominance of race or gender. Differential diagnosis includes joint hypermobility syndrome, Marfan syndrome, osteogenesis imperfecta, among others. For Araújo et al, Marfan syndrome is also a connective tissue disease, which mainly involves the cardiovascular, musculoskeletal and visual systems. The most serious problems include aortic root dilation and dissection. [24,25] According to Mizuta et al, the Klippel-Feil syndrome was described by Maurice Klippel and Andre Feil, in 1912. It is a rare congenital disease, 
belonging to the group of so-called craniocervical joint malformations. [26]

Santos et al, describe that Gastroschisis affects $0.31 \%$ and is a malformation characterized by a defect in the closing of the abdominal wall associated with the exteriorization of intra-abdominal structures, mainly the fetal intestine. Martillotti et al report that gastroschisis is observed with a failure of continuity in the abdominal wall, usually to the right of the umbilical cord, through which the intestinal loops are exteriorized in the amniotic cavity, sometimes accompanied by other organs. Due to the absence of a membrane covering the herniated content, it is free and in direct contact with the amniotic fluid. [27,28]

Epidermolysis bullosa affects $0.21 \%$ of cases and, according to Ângelo et $\mathrm{al}$, it is a rare hereditary dermatosis, characterized by the development of blisters in the cutaneous-mucosal region of the entire body, in response to minimal trauma, heat or no apparent cause, which may manifest at birth or during the first years of life. According to Gonçalves et al, there are prospects for the development of gene therapies in the future, care should start from birth. Clinical support aims to prevent and treat blisters, infections, retractions and synechiae. In cases of tissue adhesion caused by excessive blisters, such as syndactyly of the hands, feet and esophageal stenosis, surgical corrections are performed. [29,30]

Achondroplasia, the least affected congenital malformation in children aged 0 to 12 years, with $0.19 \%$. Uemura et al report that the disease is known as Parrot's Disease and is the main cause of genetic dwarfism, being a classic dominant disease with low incidence. In addition to short stature, the patient presents as clinical signs: spinal deformities, macrocephaly, hydrocephalus and hands with short and thick fingers in a trident and as oral manifestations: maxillary atresia or hypoplasia, open bite, soft palatal cleft and dental changes in number and shape. [31]

\section{CONCLUSION}

Congenital malformations are rare anomalies and this study concluded that they are mostly associated with male gender, early age and with a predominance of cardiac and circulatory alterations. The mapping of these malformations can contribute to improvements in the specific hospital sector and investment in technology in equipment and professional training in surgical procedures and techniques.

\section{REFERENCES}

1. Organização Mundial da Saúde (OMS). Anomalias Congênitas 2016. http://www.who.int/mediacentre/factsheets/fs370/en/ (acessado 11 de março de 2018).

2. RODRIGUES, L.S. et al. Características das crianças nascidas com malformações congênitas no município de São Luís, Maranhão, 2002-2011. Epidemiol. Serv. Saúde, Brasília, 2014; 23(2): 295-304.

3. LEITE, D.L. MIZIARA, H. VELOSO, M. Malformações Cardíacas Congênitas em Necropsias Pediátricas: Características, Associações e Prevalência. Arq Bras Cardiol 2010; 94(3): 294-299.

4. BOYLE, B. et al. Estimating the global burden of diseases due to congenital anomaly: an analysis of European data. Arch Dis Children Fetal Neonatal Ed., 2018; 103(1): F22F28.

5. CARDOSO, M.R. et al. Cardiopatias congênitas e malformações extracardíacas. Rev Paul Pediatr., 2013; 31(2): 243-251.

6. MENDES, C.Q.S. et al. Prevalência de nascidos vivos com anomalias congênitas no município de São Paulo. Rev. Soc. Bras. Enferm. Ped., 2015; 15(1): 7-12.

7. COSME, H.W.; LIMA, L.S.; BARBOSA, L.G. Prevalence of congenital anomalies and their associated factors in newborns in the city of São Paulo from 2010 to 2014. Rev Paul Pediatr., 2017; 35(1): 33-38.

8. GILI, J.A. et al. Análise descritiva da taxa de prevalência de nascimento alto clusters geográficos de anomalias congênitas na América do Sul. BIRTH DEFECTS RESEARCH (PART A), 2016; 106: 257-266.

9. PAWLUK, M.S. et al. Determinantes sociais adversos e risco de anomalias congênitas. Arch Argent Pediatr., 2014; 112(3): 215-223.

10. BELO, W.A.; OSELAME, G.B.; NEVES, E.B. Perfil clínico-hospitalar de crianças com cardiopatia congênita. Cad. Saúde Colet., Rio de Janeiro, 2016; 24(2): 216-220.

11. MARÔCO, J. Análise Estatística com o SPSS Statistics. 7 ed. Pêro Pinheiro - Portugal: Gráfica Manoel Barbosa \& Filhos, 2018: 657-780.

12. FONSECA FILHO, F.F. FERREIRA, R.C. MARTINS, G M. Estado Atual do Tratamento do pé torto congênito. Clínica ortopédica. Rio de Janeiro: Medsi, 2001: 283-307.

13. HURTADO, G.L.P et al. Prevalência de defeitos congênitos em Risaralda, 2010-2013. Biomedical, 2016; 36: 556-563.

14. MURRAY, J.C. Gene/environment causes of cleft lip and/or palate. Clin Genet 2002; 61: 248-256.

15. ALBERTO, M.V.L. et al. Anencephaly: Causes of congenital malformation. Rev Neurocienc., 2010; 18(2): 244-248.

16. HOROVITZ, D.G.; LLERENA JUNIOR, J.C., MATTOS, R.A. Atenção aos defeitos congênitos no Brasil: panorama atual. Cad. Saúde Pública 2005; 21(4): 1055-1064.

17. RODOVALHO J. et al. Osteogenesis Imperfecta - Case Report. Repositório Universidade Federal de Goiás UFG, 2014; 16.

18. PICADO-VAQUERO, A. et al. Developmental dysplasia of the hip: update of management. Rev. EOR. 2019; 4

19. BABCOCK, D.S. et al. Displasia do Desenvolvimento do Quadril. Colégio Brasileiro de Radiologia e Diagnóstico por Imagem. 2017; 04(2): 921-929.

20. LUCCHESE, I.C. et al. Neurofibromatose: relato de caso. Rev. Bras. Cir. Plást. 2018; 33(Supl. 1): 136-137.

21. FRIEDMAN, J.M. Epidemiology of neurofibromatosis type 1. Am J Med Genet. 1999; 89(1):1-6. PMID 10469430

22. MARANHÃO, C.P.M. et al. Congenital upper urinary tract abnormalities: new images of the same diseases. Review Article. Radiol Bras. 2013; 46(1): 43-50.

23. SACCANI, et al. Artrogripose Múltipla Congênita: Relato de Caso. Revista Digital, Buenos Aieres, 2008; 116.

24. ESPÓSITO, A.C.C. et al. Síndrome de Ehlers-Danlos, variante clássica: apresentação de um caso e revisão da literatura. Diagn Tratamento. 2016; 21(3):118-121.

25. ARAÚJO, M.R. et al. Síndrome de Marfan: novos critérios diagnósticos, mesma abordagem anestésica? Relato de caso e revisão. Rev. Bras Anestesiol. 2016; 66(4):408-413.

26. MIZUTA, N.A.; LACOMBE, P. Klippel-Feil Syndrome: therapeutic intervention through the Holistic Gymnastics - method Ehrenfried. Nova Fisio Científica, 2006.

27. SANTOS, M.M.; TANNURI, U.; MAKSOUD, J.G. Alterations of enteric nerve plexus in experimental gastroschisis: is there a delay in the maturation. J Pediatr Surg 2003; 38(10): 1506-1511.

28. MARTILlOTTI, G. et al. Predicting Perinatal Outcome from Prenatal Ultrasound Characteristics in Pregnancies Complicated by Gastroschisis. Fetal Diagn Ther. 2016; 39(4): 279-286. 
29. ÂNGELO, M.M.F.C. et al. Clinical Manifestations of Epidermolysis Bullosa: A Literature Review. Pesq Bras Odontoped Clin Integr, João Pessoa, 2012; 12(1):135-142.

30. GONÇALVES, G.A.R.; PAIVA, R.M. Terapia Gênica: avanços, desafios e perspectivas. REVENDO CIÊNCIAS BÁSICAS. Einstein, 2017; 15(3).
31. UEMURA, S.T. et al. Acondroplasia - Relato de caso clínico. J Bras Odontopediatr Odontol Bebê, Curitiba, 2002; 5(27): 410-414.
Ready to submit your research? Choose Auctores and benefit from:

* fast, convenient online submission

* rigorous peer review by experienced research in your field

* rapid publication on acceptance

* authors retain copyrights

* unique DOI for all articles

* immediate, unrestricted online access

At Auctores, research is always in progress.

Learn more www.auctoresonline.org/journals/clinical-cardiology-andcardiovascular-interventions 